\title{
Socioeconomic characteristics and quality of life of urban and rural elderly people with heart disease
}

\author{
Características socioeconômicas e qualidade de vida de \\ idosos urbanos e rurais com doenças cardíacas \\ Características socioeconómicas y la calidad de vida de los \\ ancianos urbanos y rurales con enfermedades cardiacas
Darlene Mara dos Santos Tavares ${ }^{\mathrm{a}}$ Glendha Oliveira Arduini ${ }^{b}$ Nayara Paula Fernandes Martins ${ }^{c}$ Flavia Aparecida Diasc Lucia Aparecida Ferreira ${ }^{a}$

DOl: $\quad$ http://dx.doi.org/10.1590/19831447.2015.03.45470

\footnotetext{
aniversidade Federal do Triângulo Mineiro (UFTM), Curso de Graduação em Enfermagem, Departamento de Enfermagem em Educação e Saúde Comunitária. Uberaba, Minas Gerais, Brasil.

b Universidade Federal do Triângulo Mineiro (UFTM), Programa de Residência Multiprofissional em Saúde. Uberaba, Minas Gerais, Brasil.

' Universidade Federal do Triângulo Mineiro (UFTM), Programa de Pós-Graduação stricto sensu em Atenção à Saúde. Uberaba, Minas Gerais, Brasil.
}

\section{ABSTRACT}

Objective: To compare the socioeconomic variables and quality of life scores (QOL) of elderly residents with heart diseases in urban and rural areas.

Method: household survey with 829 urban and 220 rural elderlies. The data were collected using: Brazilian Questionnaire for Functional and Multidimensional Assessment, WHOQOL-BREF and WHOQOL-OLD. The collection in the urban area was from June to December of 2008 and, in the rural area, from June 2010 to March 2011. Chi-square, $t$-student and multiple linear regression $(p<0.05)$ tests were used. Results: The proportion of women and elderlies with 75 years of age and over was higher in urban areas. Lower scores among urban elderlies physical and social relations were observed, and; facets autonomy, past, present and future activities and intimacy; for the rural elderlies, the environment, sensory abilities, death and dying.

Conclusion: the urban elderlies showed a lower QOL score in most areas and facets compared to rural elderlies.

Keywords: Elderly. Rural population. Urban population. Quality of life. Cardiovascular diseases. Health care.

\section{RESUMO}

Objetivo: comparar as variáveis socioeconômicas e os escores de qualidade de vida (QV) de idosos com doenças cardíacas residentes nas zonas urbana e rural.

Método: inquérito domiciliar com 829 idosos urbanos e 220 rurais. Os dados foram coletados utilizando-se: Questionário Brasileiro de Avaliação Funcional e Multidimensional, WHOQOL-BREF eWHOQOL-OLD. A coleta na zona urbana foi de junho a dezembro de 2008, e na rural, de junho de 2010 a março de 2011. Utilizaram-se testes qui-quadrado, $t$-Student e regressão linear múltipla $(p<0,05)$.

Resultados: a proporção de mulheres e idosos com 75 anos e mais foi superior na zona urbana. Observaram-se menores escores entre idosos urbanos nos domínios físico e relações sociais e facetas autonomia, atividades passadas, presentes e futuras e intimidade; para os rurais, no meio ambiente, funcionamento dos sentidos e morte e morrer.

Conclusão: idosos da zona urbana apresentaram menores escores de QV em mais domínios e facetas comparados aos rurais.

Palavras-chave: Idoso. População rural. População urbana. Qualidade de vida. Doenças cardiovasculares. Atenção à saúde.

\section{RESUMEN}

Objetivo: comparar las variables socioeconómicas y de calidad de vida (QOL) de los residentes de edad avanzada con enfermedades del corazón en las zonas urbanas y rurales.

Método: encuesta de hogares con ancianos 829 urbanos y 220 rurales. Los datos fueron recolectados a través de: Cuestionario brasileño de Evaluación Funcional y multidimensionales, WHOQOL-BREF y WHOQOL-OLD. La recolección en el área urbana fue de junio a diciembre de 2008, y en las zonas rurales de junio de 2010 a marzo de 2011. Se utilizaron pruebas de chi-cuadrado, t-Student y regresión lineal múltiple $(p<0,05)$.

Resultados: la proporción de mujeres y personas de 75 años y más era mayor en el área urbana. Se observaron puntuaciones más bajas entre ancianos urbano en las relaciones físicas y sociales, y; facetas autonomía, pasado, presente y las futuras actividades e intimidad; para el desarrollo rural, el medio ambiente, las capacidades sensoriales y de la muerte y el morir.

Conclusión: Ios mayores en el área urbana tenían puntuaciones de calidad de vida más bajos en la mayoría de las áreas y facetas en comparación con los del área rural.

Palabras clave: Anciano. Población rural. Población urbana. Calidad de vida. Enfermedades cardiovasculares. Atención a la salud. 


\section{DINTRODUCTION}

Aging can foster the emergence of non-communicable diseases (NCD) ${ }^{(1)}$ with emphasis on cardiovascular diseases among the elderly; making their health a major focus of attention ${ }^{(1)}$. Among them is heart disease, with a prevalence of $17.3 \%$ in this Brazilian population (1).

Scientific literature shows that socioeconomic factors such as the male gender, age and inadequate lifestyle habits can influence the prevalence of hospitalizations related to these morbidities. Added to this are the environmental aspects, which may encourage its development through exposure to pollution and stressful work activities. These aspects were highlighted in a survey conducted in Italy with and urban and rural adults and elderlies, which noted that there were more hospitalizations from heart disease among residents in urban areas ${ }^{(2)}$.

It is noteworthy that the health care of this population is a challenge for health services because of the impact of heart disease in daily life of the elderly. In this context, we emphasize the role of nurses considering their performance in these areas with the purpose of monitoring and controlling the health conditions of elderly people with chronic diseases.

It is known that access to health services and drugs are greater in urban areas compared to rural areas ${ }^{(3)}$. In addition, the dislocations from the place of residence to carry out medical consultations can be difficult for elderlies who rely on family or live in remote areas, devoid of regular public transport, or with irregular topography, making it difficult to walk to the bus stop location ${ }^{(3)}$. It is emphasized that access should be considered in its various forms, namely: geographical, cultural, economic and functional ${ }^{(4)}$. These difficulties may favor the under-diagnosis in rural areas and consequently influence disease control and quality of life (QOL).

It is known that symptoms such as fatigue and dyspnea resulting from heart disease may have a negative effect on QOL; pain can contribute to greater limitations, or act as a constant reminder of the disease, thus, also exerting a stronger influence on QOL ${ }^{(5)}$. In this perspective, it is believed that the elderly residents with heart diseases in urban areas have higher QOL scores and better socioeconomic conditions. However, an investigation performed with adults and the elderly in Taiwan showed better results of subclinical markers of cardiovascular disease among those living in forest environments, suggesting the need for comparative studies with urban areas ${ }^{(6)}$.

Thus, considering the epidemiology of heart disease, the lack of studies focusing on the impact of the disease on QOL of the elderly according to the place of residence, as well as territorial specificities, it is believed that this study may contribute to an increased reflection on health planning considering the population characteristics in different spaces.

To conduct this research, the QOL concept established by the World Health Organization (WHO) was used, namely: "the individual's perception of their position in life in the context of culture and value systems in which they live and in relation to their goals, expectations, standards and concerns" (7: 1405). Please note that the World Health Organization considers elderly individuals as those with 60 years of age or older ${ }^{(8)}$, which is the definition adopted for this study. Thus, the objective was to compare the socioeconomic variables and the QOL scores of elderlies with heart diseases who reside in urban and rural areas.

\section{METHODS}

Household, analytical, cross-sectional and observational survey, part of two subprojects. These comprise a longitudinal proposal accompanying the health conditions of the elderly, since 2005, in the city of Uberaba, Minas Gerais, being conducted by the Research Group on Public Health, of the Universidade Federal do Triângulo Mineiro (UFTM). The first sub-project, "Quality of life of elderly residents in the city of Uberaba", was developed with elderly residents in an urban area and the data was collected in the period from June to December 2008. The second, "Health and quality of life of rural elderly population in the city of Uberaba," was developed in rural areas between June 2010 to March 2011; the extensive collection period is justified by the difficult access to farms.

The sample calculation of the urban area considered $95 \%$ confidence, $80 \%$ test power and a margin of error of $4.0 \%$ for the interval estimates, and an estimated ratio of $\pi=0.5$, totaling 2,683 elderlies. Of this number, 540 were excluded for not having been found after three attempts by the interviewer (200); refusals (174); deaths (142) and hospitalizations (25). Consequently, interviews were held with 2,143 elderlies, of which 829 reported heart disease.

In rural areas, due to the imprecision of the number of elderlies who actually reside in this locality, the survey used the records of this population, a process that was conducted by the Family Health Strategy (FHS) covering 100\% of the area. The survey obtained the population list provided by the Municipal Health Department in January 2010, with 1,297 seniors. Interviewers went to all residences and 447 
elderlies were excluded due to: change of address (117), presenting cognitive decline (105), and refusal (75), have not been found after three attempts of the interviewer (57), death (11), hospitalization (3) and other reasons (79). Consequently, interviews were held with 850 elderlies, of which 220 reported heart disease.

The inclusion criteria of this study were living in urban or rural areas of Uberaba-MG, being 60 years or older without cognitive decline and self-referring to having heart disease (such as acute myocardial infarction, angina, among others). Given the sample size, it was decided that self-reported diseases should be verified, a method commonly used in population surveys, due to the impossibility of diagnosis.

Data were collected, at the homes, by 12 experienced interviewers in urban areas and 14 in rural areas. They were trained to fill out the data collection instrument and on how to approach the interviewee. Field supervisors accompanied the collection.

Cognitive assessment was performed by applying the Mini Mental State Examination (MMSE). In the urban area, the survey used the reduced and validated test by researchers of the Health, Welfare and Aging Project (SABE) ${ }^{(9)}$, and cognitive deterioration indicated by scores less than or

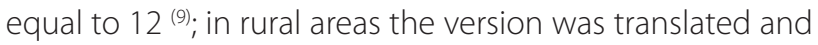
validated in Brazil ${ }^{(10)}$ with the following cut-off points: 13 for illiterates, 18 for low / medium education (1-11 years) and 26 for high school education (over 11 years) (10). The change of instrument in the countryside is because researchers consider the cut-off points more appropriate for the target population.

To obtain self-reported socioeconomic, morbidities variables, the survey used part of the Brazilian Functional, and Multidimensional Assessment Questionnaire (BOMFAQ) previously employed in a study with elderlies (11).

Quality of life was measured using the instruments: World Health Organization Quality of Life - BREF (WHOQOL-BREF) ${ }^{(12)}$ and World Health Organization Quality of Life Assessment for Older Adults (WHOQOL-OLD) ${ }^{(13)}$, both validated in Brazil. The WHOQOL-BREF is a generic instrument composed of four domains: physical; psychological; social relationships; environment ${ }^{(12)}$. The WHOQOL-OLD is a specific module for the elderly, complementary to the WHOQOL-BREF, consisting of six facets: sensory abilities; autonomy; past, present and future activities; social participation; death and dying, and; intimacy ${ }^{(13)}$. Both scores range from 0 to 100 points, while the highest value corresponds to higher quality of life.

The variables studied were socioeconomic, QOL domains and facets.
These data were processed in spreadsheets in the Ex$\mathrm{cel}^{\oplus}$ program with double entries, with the subsequent consistency between the two banks being established. Afterwards, corrections were made through the referral to the original interview in cases of inconsistent data.

The database was transported to the Statistical Package for Social Sciences (SPSS), version 17.0, and the data were analyzed using frequency distribution, mean and standard deviation and chi-square and t-Student tests. The critical level used corresponded to $5 \%(p<0.05)$. To eliminate possible confounding factors, gender and age group (60 75 and 75 years) through adjusted prevalence chance ratios (RCP) and multiple linear regression adjusted comparisons pursuant to place of residence. Age stratification was based on the Brazilian Institute of Geography and Statistics that uses this index to describe social and health data in the elderly ${ }^{(1)}$.

The Ethics Committee in Research with Human Beings of UFTM, protocols N. 897 and N. 1477, approved the projects. The interview was conducted after the elderlies signed the Free and Informed Consent Form.

\section{QRESULTS}

In urban areas, there was a higher proportion of women; seniors aged 75 and over, and; who lived without a partner, even after the adjustment (Table 1).

In Table 1, below, is the frequency distribution of socioeconomic variables of the elderly.

In the QOL analysis, measured by WHOQOL-BREF, the highest percentage of elderlies with heart disease in urban areas (73.6\%) and rural areas (48.6\%) assessed it as good. Most urban (61.4\%) and rural (58.2\%) elderlies were satisfied with their own health.

The highest and lowest QOL scores are in Table 2. Comparing the groups, the elderlies with heart disease from the urban area had lower average scores in physical $(p<0.001)$ and social relations ( $p<0.001)$, after adjustment (Table 2$)$. Regarding environment, $(p=0.012)$ urban elderlies had a higher mean score compared to those from rural areas, even after adjustment (Table 2).

The operating aspects of the senses $(p<0.001)$ and death and dying $(p=0.005)$ mean scores were higher in urban areas, remaining after adjustment (Table 2). With regard to autonomy facets ( $p<0.001)$, past, present and future activities $(p=0.001)$ and intimacy $(p<0.001)$, the scores were lower in urban areas, remaining distinct after the adjustment (Table 2 ).

In Table 2, below, are the QOL scores of elderly people with heart disease. 
Table 1 - Frequency distribution of socioeconomic variables of elderly people with heart diseases according to place of residence. Uberaba-MG, 2013

\begin{tabular}{|c|c|c|c|c|c|c|}
\hline \multirow{2}{*}{ Variables } & Urban & Rural & \multirow{2}{*}{$x^{2}$} & \multirow{2}{*}{$\boldsymbol{p}$} & Adjusted analysis & \multirow{2}{*}{$p^{*}$} \\
\hline & $\mathbf{N}(\%)$ & $\mathbf{N}(\%)$ & & & CPR (IC) & \\
\hline \multicolumn{7}{|l|}{ Sex } \\
\hline Male & $285(34,4)$ & $101(45,9)$ & 9.939 & 0.002 & $0.602(044-0.81)$ & 0.001 \\
\hline Female & $544(65,6)$ & $119(54,1)$ & & & & \\
\hline \multicolumn{7}{|l|}{ Age (in years) } \\
\hline $60+75$ & $542(65,4)$ & $151(73,2)$ & 4.788 & 0.029 & $0.668(0.47-0.93)$ & 0.018 \\
\hline$\geq 75$ & $287(34,6)$ & $59(26,8)$ & & & & \\
\hline \multicolumn{7}{|l|}{ Marital status } \\
\hline No companion & $436(52,7)$ & $61(27,7)$ & 43.325 & $<0,001$ & $2.734(1.95-3.81)$ & $<0,001$ \\
\hline With companion & $392(47,3)$ & $159(72,3)$ & & & & \\
\hline \multicolumn{7}{|l|}{ Housing arrangement } \\
\hline Lives alone & $102(12,3)$ & $25(11,4)$ & 0.144 & 0.704 & $1.046(0.65-1.67)$ & 0.850 \\
\hline Lives with someone & $727(87,7)$ & $195(88,6)$ & & & & \\
\hline \multicolumn{7}{|l|}{ Education (years) } \\
\hline No schooling & $194(23,6)$ & $61(27,7)$ & 1.622 & 0.203 & $0.760(0.54-1.06)$ & 0.115 \\
\hline With education & $629(76,4)$ & $159(72,3)$ & & & & \\
\hline \multicolumn{7}{|l|}{ Individual income } \\
\hline Without income & $75(9,1)$ & $25(11,4)$ & 1.003 & 0.317 & $0.732(0.44-1.20)$ & 0.219 \\
\hline With income & $747(90,9)$ & $195(88,6)$ & & & & \\
\hline
\end{tabular}

Source: Survey data, 2013.

* Adjusted by age and sex; POR (prevalence odds ratio); $95 \% \mathrm{Cl}=95 \%$ confidence interval for the odds ratio.

aMinimum wage corresponded to between BRL 510.00 and BRL 540.00 (14)

\section{DISCUSSION}

The prevalence of females (64.8\%) and elderlies $60+69$ years (60.4\%) was found in a survey among elderlies using medications for chronic diseases such as heart disease, in the city of Carlos Barbosa-Rio Grande do Sul ${ }^{(3)}$, which is consistent with this research.

Regarding marital status, divergent results were found in research conducted in Carlos Barbosa-Rio Grande do Sul, whereas in urban areas, $68.1 \%$ of the elderly had a partner, and in the countryside, $75.5 \%{ }^{(3)}$. In another study of adults and elderly with coronary artery disease carried out in the urban area of Ribeirão Preto-São Paulo, 66.7\% were married ${ }^{(15)}$, differing from this investigation.

Concerning self-assessment of $\mathrm{QOL}$, an international survey among adults and the elderly with cardiovascular disease showed negative influence on $\mathrm{QOL}{ }^{(5)}$, where it may be related morbidity. The positive self-assessment obtained in this study suggests the reflection of other aspects that influence $\mathrm{QOL}$, such as living conditions ${ }^{(16)}$.
Regarding satisfaction with the status of the national health survey conducted between adults and elderly patients with heart failure, it showed that the perception of $\mathrm{QOL}$ relates to everyday and the ordinary activities ${ }^{(17)}$, and can reflect positively in this regard.

Analysis of the higher scores in social relations in both locations is convergent with studies among older adults in rural Nova Bassano-Rio Grande do Sul; social support networks in partnership with family support reflect the lives of the elderly ${ }^{(18)}$, and enable repercussions in care of the cardiac diseases, favoring the independent social relations in the place of residence. As for the lower scores in the urban area, in the physical aspect of the inquiry carried out in Rio de Janeiro-Rio de Janeiro, conducted with elderly patients with heart failure, impact on functional capacity contributing to physical limitations ${ }^{(19)}$ was revealed. In rural areas, the lowest scores in the environment can be justified by the impairment of physical security and protection, with less availability of health care and social aspects evaluated in this domain ${ }^{(12) .}$ 
Table 2 - QOL scores, according to domains of the WHOQOL-BREF and WHOQOL-OLD facets according to the place of residence. Uberaba-MG, 2013

\begin{tabular}{|c|c|c|c|c|c|c|}
\hline & Urban & Rural & \multirow{2}{*}{$\boldsymbol{t}$} & \multirow{2}{*}{ d } & \multirow{2}{*}{$\boldsymbol{\beta}$} & \multirow{2}{*}{$p^{*}$} \\
\hline & Average & Average & & & & \\
\hline \multicolumn{7}{|l|}{ Domains } \\
\hline Physical & 55.3 & 63.6 & 6.985 & $<0,001$ & -0.193 & $<0,001$ \\
\hline Psychological & 65.8 & 68.1 & 2.286 & 0.023 & -0.060 & 0.052 \\
\hline Social relations & 69.0 & 72.9 & 4.687 & $<0,001$ & -0.128 & $<0,001$ \\
\hline Environment & 63.4 & 61.3 & -2.200 & 0.028 & 0.078 & 0.012 \\
\hline \multicolumn{7}{|l|}{ Facets } \\
\hline Sensory abilities & 80.0 & 72.8 & -4.442 & $<0,001$ & 0.164 & $<0,001$ \\
\hline Self-employed & 59.9 & 67.3 & 6.015 & $<0,001$ & -0.199 & $<0,001$ \\
\hline Past, present and future activities & 65.9 & 69.2 & 3.478 & 0.001 & -0.108 & 0.001 \\
\hline Social participation & 64.9 & 66.5 & 1.524 & 0.128 & -0.024 & 0.432 \\
\hline Death and dying & 77.4 & 72.4 & -2.697 & 0.007 & 0.087 & 0.005 \\
\hline Intimacy & 70.0 & 74.5 & 3.412 & 0.001 & -0.112 & $<0,001$ \\
\hline
\end{tabular}

Source: Survey data, 2013

* Adjusted by place of residence, gender and age

As for the comparison between groups, the lowest score in the physical urban domain may be related to physical restrictions and disabilities caused by the disease, which may cause dependency and hospitalization (19), in consequence. Survey with adults and urban elderly in Ceará showed they had dyspnea when performing their activities and work impairments ${ }^{(20)}$ which can negatively influence physical aspects.

Thus, in this study, the lowest score in the urban domain referred to may be related to a higher proportion of women, and elderlies aged 75 and over, who may have more comorbidities that negatively affect their health condition, such as dependency on medication or treatments, and work capacity, evaluated in this item ${ }^{(12)}$. Accordingly, it is believed that nursing can contribute by identifying the impact of heart disease coupled to the physical aspect comorbidities. From there, one can come up with a plan of action guided by the problems mentioned by the elderly.

The lowest scores in social relations in urban areas compared to rural areas highlights the need for reflection on this aspect. These relationships may facilitate or boost promoting and/or health protectors, considering that among older adults with heart disease support from friends and family contributes to the acceptance of the disease ${ }^{(19)}$. It also infers that the higher percentage of urban elderlies without a partner present in this study may have contributed to this result. It is emphasized that a so- cial support network is important in coping with a chronic illness can provide the elderly improved self-esteem and family relationships ${ }^{(19)}$.

Transport constraints and the distance of health resources can explain the lowest scores in the environment domain in rural areas compared to urban areas, aspects observed during data collection; these aspects may affect the physical security of the elderly due to the major difficulties of displacement in face of their health needs, arising from the heart condition. This fact could negatively influence the possible health related needs in the rural area still related to scarce health resources. This result highlights the need for health services in these locations to develop monitoring strategies and to monitor the health of this population. Nursing can contribute through regular home visits.

The highest scores evidenced in the sensory abilities facet among urban elderlies may be related to a possible increase in access to health services for monitoring physiological and / or pathological changes that affect the sensory system. As for intimacy in the rural area, the higher proportion of married elderlies, considering that this domain assesses the personal and intimate relationships (12), can explain the higher scores. Regarding the lower scores for the autonomy of the urban elderly, it is inferred that in this locality, family members, highlighting the need to identify which aspects have contributed to this result, minimize the freedom of decision. In turn, the smaller social participation 
in the rural area may be related to lack of social activities, as well as the distance and difficulties of transport.

The comparison between the groups, the larger rural impact on the sensory abilities, evidenced by larger urban scores may be related to unmet needs in rural areas. It is believed that the occurrence of these health problems are arising from the existing socioeconomic differences in the rural areas, that interfere negatively in access to health services and quality of life. It therefore adds, to the higher proportion of elderly people without income in rural areas found in this study. This may contribute to difficulties in the acquisition of corrective equipment such as eyeglasses and hearing aids, when needed. In this sense, it is suggested that complaints related to sensory abilities be evaluated, and the elderlies referred to specialized medical consultation. Moreover, it adds to the possible need for social care, considering the income of the elderlies in this study, which could hinder the acquisition of corrective equipment after diagnosis of their needs.

The lowest score in the autonomy facet in the urban area indicates less freedom for decision making among these elderlies. It is worth highlighting that the elderlies with heart failure establish coping strategies of the signs and symptoms triggered by morbidity. Additionally, the continuous treatment, which requires changes in habits and adapting the limitations that result from physical symptoms. These changes usually conflict, for they interfere in various aspects of life of the individuals ${ }^{(19,20)}$. In addition, it appears that the lowest score among the urban elderly may be related to lower scores in the physical domain due to the greater impact caused by the limitations imposed by the disease ${ }^{(19)}$.

As such, it is suggested that these aspects be investigated through the monitoring of their health. Nursing, in the care of elderlies with heart failure, should recognize their experience with the disease, evaluating its effects on physical capacity and autonomy. From there, it should stimulate their potential and support in order for the individuals to learn ways to take care of themselves throughout everyday experiences ${ }^{(19)}$.

Furthermore, actions can be carried out with the elderly and their families to maximize their autonomy. The family assumes an important role to support the individual in fighting the disease, in consequences, treatment and lifestyle change ${ }^{(20)}$.

Regarding the lower scores in the past, present and future activities in urban areas compared to rural, urban research with adults and elderly patients with heart failure in Ceará, a feeling of helplessness related to work removal and daily activities resulting from symptoms. They felt helpless and invalid due to the fact they no longer develop the above activities ${ }^{(20)}$, which could influence their future expectations. This result implies the need to identify, with the elderly, their prospects for the future. Nursing can, seek alternatives that bring personal satisfaction to the elderly through group activities.

The highest scores regarding the death and dying facet in the rural areas compared to the urban area may be related to the higher proportion of younger elderlies in this locality; they continue to perform their work activities remaining active, which was observed during the data collection performed for the survey in rural areas. Thus, the debate on issues related to death and dying may be less common among these elderlies.

The lowest score found in urban areas compared to rural areas in the intimacy facet can be related to the higher percentage of unmarried elderlies considering that this domain assesses personal and intimate relationships ${ }^{(13)}$. In this context, the nurse and the multidisciplinary team should address this issue clarifying questions to facilitate adaptation to the disease, treatment adherence and problems in relationships ${ }^{(20)}$.

\section{- CONCLUSION}

The hypothesis of this study that the urban elderly have higher QOL scores and better socioeconomic conditions in relation to the rural area was partially refuted; no significant differences were observed in some socioeconomic conditions such as education and income, and lower scores were observed in some aspects of QOL of the rural elderly.

In urban areas, the proportion of women, older elderlies and unmarried elderlies was higher than that in rural areas. Concerning QOL, urban elderlies had lower scores in physical domains and social relations and autonomy facets, past, present and future activities and intimacy; as for the environment domain and sensory abilities and death and dying, elderlies from the urban area had higher scores.

This study highlights the need for monitoring of urban elderlies to minimize the impact of the disease on the physical, social, autonomy aspects, and future expectation. The nurse can, through nursing consultations and home visits, reflect on these aspects with relatives, identifying the limitations imposed by the disease and identifying improvement alternatives. In rural areas, strategies to facilitate the elderlies' access to health services should be developed in order to contribute to minimizing the impact of sensory abilities.

The cross cut that does not establish causal relationships, and the self-reported heart disease that may under- 
estimate the prevalence of the disease due to underdiagnoses stands out as a study limitation.

\section{REFERENCES}

1. Instituto Brasileiro de Geografia e Estatística. Síntese de indicadores Sociais: uma análise das condições de vida da população brasileira [Internet]. 2010 [cited in 2012 abr. 26]. Available in: http://www.ibge.gov.br/home/estatistica/populacao/ condicaodevida/indicadoresminimos/sinteseindicsociais2010/SIS_2010.pdf

2. The santangelo, Albani S, Atteritano M The Cappello, Malaguarnera M Pavano $S$, et al. Prevalence of cardiovascular pathologies in elderly population living in an industrialized area, compared to a control population residing in a rural area. Arch Gerontol Geriatr. 2012;55(3):702-5.

3. Pizzol TSD, Pons ES, Hugo FN, Bozzetti MC, Sousa MLR, Hilgert JB. Uso de medicamentos entre idosos residentes em áreas urbanas e rurais de município no sul do Brasil: um estudo de base populacional. Cad Saúde Pública. 2012;28(1):104-14.

4. Unglert CVS, Rosenburg CP, Junqueira CB. Acesso aos serviços de saúde: uma abordagem de geografia em saúde pública. Rev Saúde Pública. 1987;21(5):439-46.

5. Djärv T, Wikman A, Lagergren P. Number and burden of cardiovascular diseases in relation to health-related quality of life in the cross-sectional population-based cohort study. BMJ Open. 2012;2(5):1-7.

6. Tsao TM, Tsai MJ, Wang YN, Lin HL, Wu CF, Hwang JS, et al. The health effects of a forest environment on subclinical cardiovascular disease and heath-related quality of life. PLoS One. 2014;9(7):e103231.

7. The WHOQOL Group (CH). The World Health Organization Quality of Life Assessment (WHOQOL): position paper from the World Health Organizations. Soc Sci Med. 1995;41(10):1403-9.

8. World Health Organization (CH). Active ageing: a policy framework [Internet]. 2002 [cited in 2015 jan. 19]. Available in: http://whqlibdoc.who.int/hq/2002/ who_nmh_nph_02.8.pdf

9. Icaza MC, Albala C. Projeto SABE: Minimental State Examination (MMSE) del estudio de dementia en Chile: análisis estatístico. Ginebra: OPAS, 1999. p. 1-18.
10. Bertolucci PHF, Brucki SMD, Campacci SR, Juliano Y. 0 mini-exame do estado mental em uma população geral: impacto da escolaridade. Arq Neuro-Psiquiatr. 1994:52(1):1-7.

11. Ramos LR, Toniolo NJ, Cendoroglo MS, Garcia JT, Najas MS, Perracini M, et al. Two-year follow-up study of elderly residents in S. Paulo, Brazil: methodology and preliminary results. Rev Saúde Pública. 1998;32(5):397-407.

12. Fleck MPA, Louzada S, Xavier M, Chachamovich E, Vieira G, Santos L, et al. Aplicação da versão em português do instrumento abreviado de avaliação da qualidade de vida "WHOQ0L-bref". Rev Saúde Pública. 2000;34(2):178-83.

13. Fleck MPA, Chachamovich E, Trentini C. Development and validation of the Portuguese version of the WHOQOL-OLD module. Rev Saúde Pública. 2006;40(5):785-91.

14. Departamento Intersindical de Estatística e Estudos Socioeconômicos (BR). Cesta básica nacional. Salário mínimo nominal e necessário [Internet]. 2013 [cited in 27 dez. 2013]. Available at: http://www.dieese.org.br/analisecestabasica/ salarioMinimo.html.

15. Gois CFL, Dantas RAS, Torrati FG. Qualidade de vida relacionada à saúde antes e seis meses após a revascularização do miocárdio. Rev Gaúcha Enferm. 2009;30(4):700-7.

16. Tavares DMS, Gavea Junior SA, Dias FA, Santos NMF, Oliveira PB. Qualidade de vida e capacidade funcional de idosos residentes na zona rural. Rev RENE. 2011;12(n.esp):895-903.

17. Barbosa RR, Franklin RV, Stefenoni AV, Moraes VD, Jacques TM, Serpa RG, et al. Análise da qualidade de vida em homens e mulheres portadores de insuficiência cardíaca. Rev Bras Cardiol. 2014;27(2):97-103.

18. Bertuzzi D, Paskulin LGM, Morais EP. Arranjos e rede de apoio familiar de idosos que vivem em uma área rural. Texto Contexto Enferm. 2012;21(1):158-66.

19. Santos ACS, Espírito Santo FH, Pestana L, Daher DV, Santana R. Insuficiência cardíaca: estratégias usadas por idosos na busca por qualidade de vida. Rev Bras Enferm. 2011;64(5):857-63.

20. Rocha LA, Silva LF. Adaptação psicossocial de pessoas portadoras de insuficiência cardíaca: diagnósticos e intervenções de enfermagem. Rev Eletrônica Enferm. 2009;11(3):484-93.

\section{Author's address:}

Darlene Mara dos Santos Tavares

Rua Jonas de Carvalho, 420, Olinda

38055-440 Uberaba - MG

E-mail: darlenetavares@enfermagem.uftm.edu.br
Received: 07.03.2014

Approved: 14.07.2015 